\title{
The Importance of Foreign Direct Investments and Instruments for their Protection
}

\author{
ZOLTÁN VÍG*
}

\begin{abstract}
In the introductory part of the article, the importance of foreign direct investments for host states are examined. Following this, non-commercial risks foreign investors are facing in the host state (e.g. taking, currency inconvertibility risk, etc.) are assessed and finally, legal instruments for the protection of these investments are considered. Legal instruments for the protection of foreign investments can be divided into domestic (host state) and international instruments. Foreign investors usually prefer international instrument as these insure impartial dispute settlement. These are individual agreements between the investor and the host country (in which the host country agrees to treat the investor equal), bilateral investment treaties (BIT) and multilateral agreements.
\end{abstract}

Keywords: FDI, non-commercial risks, investment protection, BIT, MIGA, ICSID, ECT

\section{INTRODUCTION}

The objective of this article is to show the importance of foreign direct investment for host states and to acquaint the reader with the investment protection instruments. During the last two decades the net inflow of foreign direct investments has showed huge growth worldwide (see Chart 1). Foreign direct investment can contribute significantly to the development and modernization of the economy. Furthermore, it can offer new technologies and technical knowledge for the modernization of key important processing industry branches (although, it is also true that developed countries frequently export-outdated technology). Foreign direct investments can also contribute to the training of the workforce and to the improvement of the management. Foreign investors can offer necessary information on foreign markets and how to use these markets and can help developing countries to access and seize foreign markets already in the hands of these foreign investors. In addition, they can facilitate privatization processes. For example, foreign capital that streamed in during the privatization process helped East European countries in transition to maintain the delicate equilibrium of the balance of payments. ${ }^{1}$ The enterprise restructuring would also have been unthinkable without the expertise and capital of foreign investors.

On the other hand, one should be under no delusion that foreign investors are investing in the hope of good profit, what is not always in the interest of the host country. The Southeast Asian economic crisis of 1997 was a good example. In countries without strict investment regulation (routing the investments into particular sectors) like Thailand or Malaysia, foreign investments went into sectors where they could realize the highest profit (e.g. financing domestic consumption, luxury goods), instead of production, research and development, thus one might say they were 'wasted'. The crisis hit these countries much harder. $^{2}$

* Associate professor, University of Szeged, Law School, Singidunum University, FEFA, e-mail: jogasz@gmail.com.

1 Stevanović (2001) 25.

2 Studwell (2013) 139-44. 


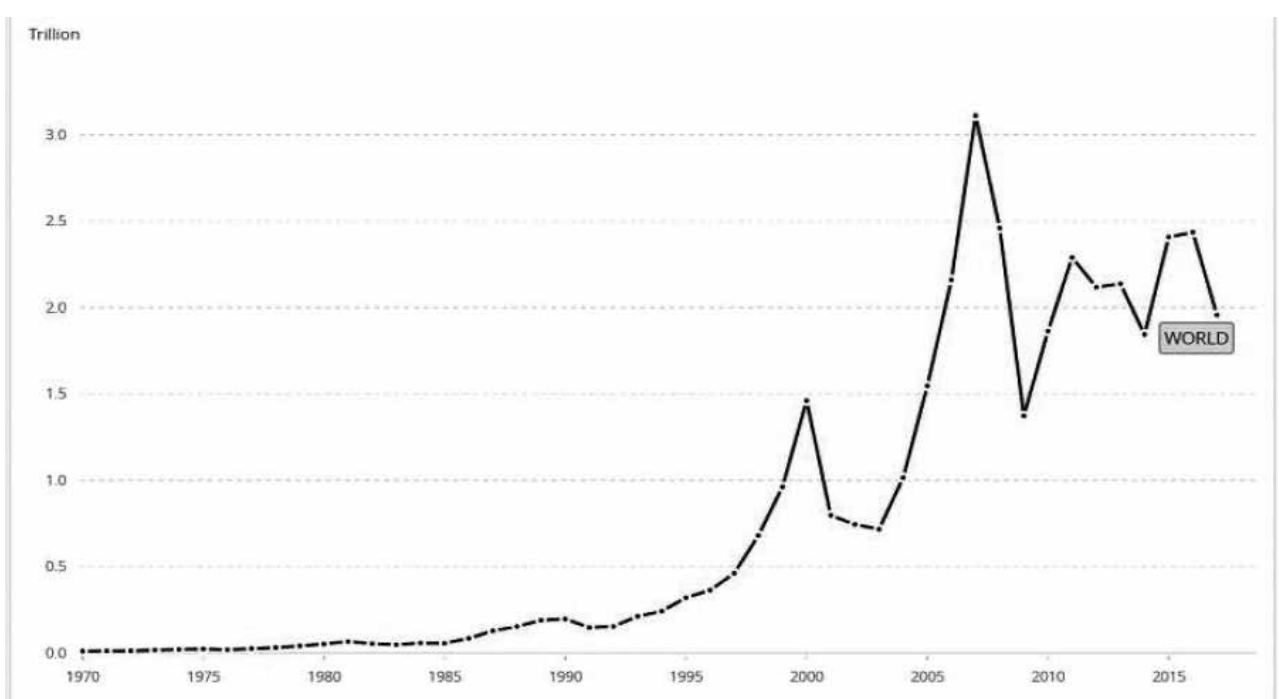

\section{Chart 1. Foreign direct investment, net inflows (BoP, current USD) ${ }^{3}$}

There is high worldwide competition to attract foreign working capital and therefore, if a country wants to attract foreign capital, it has to initially find out what are motivational factors of investors. There are many motivational factors that encourage foreign investors to invest in a country. Economist John H. Dunning categorizes these factors into the four groups: investments aimed at (1) acquiring resources, (2) securing markets, (3) enhancing efficiency, (4) establishing strategic advantages for the investors to improve their long-run competitiveness. ${ }^{4}$ These motivational factors cannot be directly influenced by the investment recipient country - these factors objectively exist. However, these factors will influence the investment policy of investors and the implementation of this policy and this can be influenced by the investment recipient country by macroeconomic conditions.

Thus, capital 'allurement', besides motivational factors, also has general macroeconomic conditions and these can be substantially influenced by the host country. These conditions involve, among others, a safe political, legal and institutional environment and of course the proper protection of foreign investments. The existence of such general conditions is essential precondition for investments. A survey of Ernst and Young international corporations during their international investments found that the most retardant force was political instability. ${ }^{5}$ Besides political stability, a well-functioning legal and judicial system is also necessary. Therefore, theoretically, political stability, a perspicuous legal system, and an efficient judicial system can raise the inflow of foreign capital.

3 Source: International Monetary Fund, Balance of Payments database, supplemented by data from the United Nations Conference on Trade and Development and official national sources, World Bank Open Data (2018) link 1.

4 Dunning, Lundan (2008) 63-77.

5 Ernst and Young (2018) link 2. 


\section{RISKS FOR FOREIGN INVESTORS}

There are two categories of risks that foreign investors have to face: commercial (e.g. rescission or cancellation of contract, suspension of performance, non-payment because of insolvency or default of the debtor, etc. $)^{6}$ and non-commercial. This latter can be any of the following: taking (expropriation, nationalization), currency inconvertibility, issues related to the transfer of profit, currency devaluation, political violence (e.g. war, terrorism, revolution), and deterioration in investment environment. ${ }^{7}$ However, with good investment protection systems (e.g. investment protection treaties, investment insurance) the loss of the investor can be minimized, though these risks cannot be avoided entirely.

Even if there is compensation paid for property taken, this, in some cases, will not gratify foreign investors. For example, important value is often constituted by the transferred technology and transferred know-how, for which there is usually no compensation paid. In addition, many investments require high initial expenditure. In the case of indirect expropriation, it is very expensive to withdraw from the host country quickly if the investment environment becomes hostile. Therefore, investors usually look for investment opportunities with low risk, which is typical for countries with long tradition of stable political and economic system.

\section{INSTRUMENTS FOR THE PROTECTION OF FOREIGN INVESTMENTS}

There are certain rules in customary international law regarding treatment of foreigners, foreign investors and their investment. These rules are mainly derived from the practice of states (and from different international treaties) and therefore are not uniform. ${ }^{8}$ First of all, it is apparent under international customary law that in principle (historically), there is no obligation to admit foreigners to the territory of sovereign states. From this, it follows that theoretically there is also no obligation on the state to allow foreigners to undertake an investment on their territory. However, if they do, it should be borne in mind that foreign investors, as a general rule, are subject to national law. States, of course, can voluntarily limit their sovereignty through treaties. In this case investors are also subject to treaties, conventions and, in some cases, even contracts concluded between investors and the host state.

Few words should be devoted also to the standards of treatment of foreign investors. The very strong protection of private property, as well as that of foreigners, that came into existence in the 19th century, following decolonization has lost its strength. Therefore it was desirable for capitalist states to develop and make recognized in international law the so-called 'minimum standard' of protection of foreigners. ${ }^{9}$ According to this theory, there are rights created and defined by international law (e.g. once a state lets the investor and its investment to enter the country, it has to ensure for it and its investment the same protection that is insured to its own citizens, and the investor in addition has the right for protection that is considered 'fair and equitable' under international law). These rights may be claimed by or on behalf, of aliens admitted to the country who lawfully acquired property. ${ }^{10}$

\footnotetext{
6 van Houtte (2002) 286.

7 Király and Mádl (1989) 43.

8 Brownlie (1998) 13-16.

9 Bergmann (1997) 39.

10 Sacerdoti (1997) 341.
} 
Foreigners, according to this standard, should be treated in a 'fair and equitable' manner. ${ }^{11}$ The theory of 'minimum standard' rejects the Calvo Doctrine according to which aliens have only those rights that are afforded to local nationals. ${ }^{12}$ This standard requires more than national treatment of foreign investors, as sometimes the national treatment of private property can be poor. The investment recipient state has to respect minimal international norms (minimum standard) of the customary international law irrespectively of what municipal law allows concerning the treatment of its own citizens in the case of taking, etc. ${ }^{13}$

States that do not respect these basic principles of 'minimum standard' and thus harm foreign investors, commit an international wrong. ${ }^{14}$ The 'equitable treatment' standard is comparable to the 'minimum standard'. This requires States to apply their law in a 'fair, reasonable, equitable and adequate manner' to foreigners. ${ }^{15}$ Capital exporting states claim that both standards should apply without any treaty provision between (or among) states. There is also a so-called 'standard of national treatment' in international law that is a special standard in connection with the treatment of foreigners and foreign investors that apply only on the grounds of a treaty (an exception might be if the host state unilaterally grants this treatment). Under this treatment investors should not have less favorable treatment than that granted to domestic investors. The standard of 'most favored treatment' requires that all the benefits conceded to any other investor or investment in the host country have to be also given to the investor or investment under 'most favored treatment'. ${ }^{16}$ This treatment can be of crucial importance if there is a strong international competition present in the field of the specific investment.

Finally, 'preferential treatment' is a kind of exception to the 'most favored standard', and is used within custom unions and free trade areas. ${ }^{17}$ Both multilateral instruments and bilateral treaties are based on the combination of the above mentioned treatment standards. ${ }^{18}$

International legal instruments for the protection of foreign investments are crucial in this field if uncertainty is to be avoided. In examining these instruments, a distinction should be made between diplomatic and legal protection of foreign investments. Here, legal protection, that is to say, legal instruments are examined, which can be divided into domestic (those of the host state) and international instruments. Foreign investors might theoretically have the right to take their case to a local court under the local laws in the host state. However, there is always the risk of bias; local courts partiality and political influence of the host state. Therefore, foreign investors prefer international instruments of protection. These can be individual agreements between the investor and the host country, bilateral investment treaties (BITs), or multilateral agreements. ${ }^{19}$ Host states are usually reluctant to conclude individual agreements with foreign investors except when the investment is of crucial importance for the host. Such agreements usually contain investment protection

11 Sacerdoti (1997) 341.

12 Vagts (1997) 408, Bergmann (1997) 40, Dixon (1993) 212-13.

13 Vagts (1997) 408, Dixon (1993) 206, van Houtte (2002) 4.

14 With committing international wrong States become liable, van Houtte (2002) 248.

15 van Houtte (2002) 4.

16 van Houtte (2002) 5.

17 van Houtte (2002) 6.

18 Sacerdoti (1997) 343-45.

19 Vörös (2015) 133-34. 
provisions, and the host states agrees to treat the investor equal (e.g. in case of dispute to accept international arbitration, etc.). However, often investors are not influential enough to conclude such individual agreements, and highly appreciate the existence of bilateral or multilateral investment protection agreements.

\section{BILATERAL INVESTMENT TREATIES}

The most important international legal tools for the protection of foreign investments are bilateral investment treaties. These treaties have proliferated enormously over the last few decades. Their spread was initiated and powered by capital exporting countries, and they have become the major international instruments through which investments are protected worldwide.

\begin{tabular}{|l|l|}
\hline \multicolumn{2}{|l|}{ Bilateral Investment Treaties } \\
\hline Total: & 2953 \\
\hline Total in force: & 2358 \\
\hline Treaties with Investment Provisions (TIPs) \\
\hline Total: & 381 \\
\hline Total in force: & 310 \\
\hline
\end{tabular}

\section{Chart 2. Bilateral investment treaties and Treaties with Investment Provisions (TIPs) $^{20}$}

For some commentators, bilateral investment treaties are tools for entrenching customary principles of international law related to the protection of foreign investment. ${ }^{21}$ Kishoiyian is of the opinion that the reason for concluding so many bilateral investment treaties in the last decades is that there is uncertainty in international law concerning the protection of foreign investment in the case of taking of foreign property (all bilateral investment treaties have special provisions establishing conditions for taking of foreign property) ${ }^{22}$ It is his opinion that it follows that these treaties are 'lex specialis between parties designed to create a mutual regime of investment protection, ${ }^{23}$ but they do not evidence customary international law. ${ }^{24}$ At the same time, somehow paradoxically, Kishoiyian argues that 'the essential function of a treaty is to represent the consent of its parties, but it may be used as well to demonstrate the existence of a rule of customary law. ${ }^{25}$ Dixon makes a distinction between law-making treaties in international law that are multilateral treaties and 'contract'

20 Source: Investment Policy Hub of UNCTAD (2018) link 3.

${ }^{21}$ Kishoiyian agrees with F.A. Mann who was on the opinion that these treaties 'establish and accept and thus enlarge the force of traditional conceptions of the law of State responsibility for foreign investment.' Kishoiyian (1993) 2. and Bergmann (1997); Király, Mádl (1989).

22 Sacerdoti (1997) 379.

23 Kishoiyian (1993) 3.

${ }^{24}$ However, accepting certain practices in international relations of States by States creates international custom, and international custom is the bases of international law. (ICJ Statute art 38 (1) (b) states: 'international custom, as evidence of a general practice accepted as law').

25 Kishoiyian (1993) 9. and Brownlie (1998) 13. 
treaties that are bilateral treaties. He suggests that this distinction means that bilateral international treaties have no effect in general on international law but have international legal effect only between the parties. ${ }^{26}$ However, it could be argued that if a body of bilateral investment treaties has evolved that support the same standard for a long period of time, it can represent customary international law. Many standards and provisions of multilateral treaties are the result of standards first applied in bilateral treaties. Some other authors state that the main idea of these treaties is to create clear international legal rules and an effective enforcement mechanism to protect foreign investments in host states. At the end of the day, violation of bilateral investment treaty is at the same time violation of international law, and it infers international responsibility. ${ }^{27}$

Bilateral investment treaties aim to protect foreign direct investments and at the same time are devices to boost investor confidence. Guarantees given on international level are usually more reliable than national guarantees of the host country. It is easier to manipulate domestic legislation than to abrogate unilaterally international treaties. For example, domestic legislation that is detrimental to foreign investors can be many times justified with social reasons. However, if international agreements are unilaterally abrogated, it can have much worse negative effect on the whole foreign policy of the country concerned (and such political decision does not affect only investments). A study of the United Nations' Center on Transnational Corporations on bilateral investment treaties reports, that although appropriate legal protection of foreign direct investments has a large influence on the willingness of foreign investors to invest in a country, the existence of bilateral investment treaties, as a matter of fact, do not influence the inflow of foreign investment. ${ }^{28}$ That is to say, generally, there cannot be proven direct conjunction between the investment inflow and the number of bilateral investment treaties concluded. The study also mentions that the existence of such a treaty is only one of several factors that can influence investors to invest to a certain country; however, this is not the most decisive one. This conclusion of the study is based on the results of empirical research. However, a well-organized regime of bilateral investment treaties can largely contribute to the growth of foreign investments. With a bilateral investment treaty regime the host state can target certain investors, grant certain privileges that make the host country more attractive, in one word it can offer a 'customized' investment environment. Thus, bilateral investment treaties have two major advantages: they offer legal protection for the investors and they help to attract investments for the investment receiving country (host state). However, Guzman claims that it only 'seems' that they are beneficial for both parties. He asserts that such treaties increase efficiency on the global level whilst at the same time they probably reduce the overall welfare of developing countries. ${ }^{29}$ This might be true, examined bilateral investment treaties concluded by large economic powers, like the United States of America show that the stronger party 'many times' imposes its conditions on the economically weaker party. This is derived from the fact that the United States is very rarely willing to depart from its model treaty. ${ }^{30}$

Besides the above-mentioned major arguments, there are many other reasons that can motivate countries to conclude bilateral investment treaties. Such treaties for example facilitate entry of investment by inducing other states to remove impediments in their

26 Dixon (2002) 25.

27 Guzman (1998) 642, Karl (1996) 3.

${ }^{28}$ United Nations Conference on Trade and Development (2005) link 4.

29 Guzman (1998) 643.

30 The latest version of the Model Bilateral Treaty is from 2012: see link 5. 
regulatory system, help investors to gain market and improve political climate between states. ${ }^{31}$ Another very important argument for, or advantage of the new generation of bilateral investment treaties, is that they offer a binding mechanism resolving investment disputes, or an important practical implications of such treaties is that their existence is usually condition for obtaining insurance against taking in the home country of the investor. $^{32}$

\section{MULTILATERAL TREATIES}

Multilateral instruments (and organizations established by them) in the field of investment protection also play an important role because of the enormous growth of investments worldwide, growing number of free trade zones and international character of the guarantees these treaties can provide for foreign investments. The rule lex posterior derogat legi priori applies regarding the relation of bilateral investment treaties and multilateral treaties. ${ }^{33}$

Discussing multilateral investment protection treaties, the Convention on the Settlement of Investment Disputes between States and Nationals of Other States should be first mentioned. This treaty established the International Centre for Settlement of Investment Disputes (ICSID) in 1965, as an autonomous international organization to facilitate the settlement of investment disputes between member states and nationals of other member states (both natural and legal persons). ${ }^{34}$ The organisation's importance is in providing conciliation and arbitration facility and rules, with a seat in Washington. ICSID arbitrators are nominated by member states; they should be experts from the field of law, commerce, industry or finances and above of all, impartial. ${ }^{35}$ However, the arbitrators can only proceed if the parties to the dispute consent in writing to submit their dispute to the Centre (usually stated in BITs or individual investment agreements). Another important provision of the Agreement is that the arbitral award of the ICSID tribunals is binding on the parties and should not be subject to any appeal or to any other remedy except those provided for in the ICSID. ${ }^{36}$

The Organization for Economic Co-operation and Development (OECD) in 1998 worked out and proposed a Multilateral Agreement on Investment (MAI). The main aim of the proposal was to establish a uniform system of investment protection with a broad multilateral framework and high standards that fosters liberalization of investment regimes and investment protection. It also planned to create an effective dispute settlement

31 Karl (1996) 5.

32 E.g., such insurance is usually obtained from international investment insurance companies (e.g., Nippon Export and Investment Insurance (see link 6) or it can be also obtained from the government of the investor, provided such scheme exists in the investor's home country (e.g., Overseas Private Investment Corporation (OPIC) that is partially financed by the government of the United States, partially from insurance fees (see link 7).

${ }^{33}$ International Law Commission, art. 30 (3) of the Vienna Convention on the Law of Treaties (2018) link 8.

${ }^{34}$ ICSID art. 25 (1) states: 'The jurisdiction of the Centre shall extend to any legal dispute arising directly out of an investment, between a Contracting State (or any constituent subdivision or agency of a Contracting State designated to the Centre by that State) and a national of another Contracting State, which the parties to the dispute consent in writing to submit to the Centre.' ICSID (2018) link 9.

\footnotetext{
35 Art. 14, ICSID (2018) link 9.

36 Art. 53, ICSID (2018) link 9.
} 
system. However, negotiations were discontinued and it seems that they will not be resumed. ${ }^{37}$

A good example for functioning multilateral investment protection treaty containing substantive law is the Energy Charter Treaty (ECT) that was launched in the beginning of the 1990s, when the energy sector offered an excellent opportunity for cooperation between the West, which had the necessary money and increased need for energy and Russia and some of neighbors states who had the energy but no money to invest into its exploitation. The ECT created a legal framework for striving towards open, efficient, sustainable and secure energy markets and also contains a whole chapter on investment promotion and protection. This chapter contains provisions related to the treatment of investors, expropriation of investment, transfers of profit. There is an ever growing case law related to the treaty, including the famous Yucos case. ${ }^{38}$

One of the main obstacles for the spread of foreign direct investments in the second half of the last century was that the non-commercial risk (nationalization, exchange restrictions, revolutions) was high. Therefore, a special type of multilateral instruments for the protection of foreign investment, a kind of insurance for foreign investors, was introduced by the Multilateral Investment Guarantee Agency (MIGA). The Agency was created by the World Bank to promote foreign direct investment in developing countries. Besides reduction of poverty, research on investment opportunities in developing countries and informing potential investors, MIGA offers investment guarantees (insurance) to foreign investors from member states (for investments in other member states) against noncommercial risk (e.g. expropriation). From the time of its establishment, it has issued 28 billion USD of investment insurance. It should be mentioned that assuror can be only citizen or legal person with its seat in a member country and only for foreign investments. In case of an insurance event, MIGA pays the compensation to the assuror and the claim cedes to MIGA. ${ }^{39}$

Finally, some of the most important modern free trade agreements, as international multilateral treaties, should be also mentioned, as they also contain investment protection provisions and there is a tendency to replace bilateral investment treaties with such treaties.

The North American Free Trade Agreement (NAFTA) is a trilateral economic agreement concluded among the United States, Mexico and Canada, whose objectives include eliminating trade barriers, promoting fair competition, increasing investment opportunities, providing effective protection of intellectual property rights and resolving disputes throughout these countries. Chapter 11 of the Agreement deals with the issue of investment protection and expropriation. The case law under this Chapter has unleashed a vast body of scholarly commentary ${ }^{40}$ and at the same time the NAFTA might serve as a model multilateral trade agreement in the future.

New generations of EU free trade agreements should be also mentioned, which among others, regulate investment protection issues. ${ }^{41}$ Economically the most significant one is the EU-Canada Comprehensive Economic and Trade Agreemen (CETA). This Agreement has entered provisionally into force in 2017 , however, provisions related to investments will

37 OECD MAI (2018) link 10.

38 The Energy Charter Treaty (2018) link 11.

39 Multilateral Investment Guarantee Agency (MIGA) (2018) link 12; Vörös (2015) 150.

40 NAFTA cases can be found on: US Department of State NAFTA cases (2018) link 13 and NAFTA Claims.com (2018) link 14.

${ }^{41}$ European Parliament (2018) link 15. 
enter into force only following its ratification. ${ }^{42}$ It contains substantive law related to investment protection similar to bilateral investment treaties (clarifies the standards of treatment, FET standard, right to regulate of the host state, etc.). However, there is a novel solution regarding procedural rules - the Agreement intends to establish a permanent investment court. ${ }^{43}$ At the same time, according to some opinions, the regulatory system under CETA might cause a 'regulatory chill' effect, meaning that host countries will abstain from environmental, labor and other legislation that might be contrary to the interest of foreign investors, fearing of high legal and compensation costs in case a dispute arise between the host state and the investor. ${ }^{44}$

\section{CONCLUSIONS}

The importance of foreign investments in a globalised world cannot be denied. There are several ways of protecting these investments. However, it can be said that the most important legal instruments for the protection of foreign investments are still bilateral investment treaties. At the same time, there is clear tendency towards their replacement by new generation multilateral free trade agreements. NAFTA and CETA are good examples for this, especially the novel solution of the latter regarding the establishment of a permanent investment court. Another issue, related to the descending importance of bilateral investment treaties, although only on regional (European) level, is a recent decision of the European Court of Justice that an arbitration clause in a bilateral investment treaty concluded between two European Union member states is incompatible with European Union law. However this decision does not invalidate automatically bilateral investment treaties in force between the member states, and there are some new arbitral decisions rejecting some of the arguments of the court in this case. ${ }^{45}$

\section{LITERATURE}

Bergmann, Heidi, Die völkerrechtliche Entschädigung im Falle der Enteignung vertragsrechtlicher Positionen (Nomos 1997).

Brownlie, Ian, Principles of Public International Law (5 ${ }^{\text {th }}$ edn, OUP 1998).

Dixon, Martin, Textbook on International Law (2nd edn, Blackstone 1993).

Dunning, John H., and Lundan, Sarianna M., Multinational Enterprises and the Global Economy $\left(2^{\text {nd }}\right.$ edn, Edward Elgar Publishing 2008).

Guzman, Andrew T., 'Why LDCs Sign Treaties That Hurt Them: Explaining the Popularity of Bilateral Investment Treaties' (1998) 38 Virginia Journal of International Law 639-88.

Karl, Joachim, 'The Promotion and Protection of German Foreign Investment Abroad' (1996) 11 ICSID Review 1-36.

Király, Miklós, and Mádl, Ferenc, A külföldi beruházások jogi védelme (Legal Protection of Foreign Investments) (ELTE 1989).

Kishoiyian, Bernard, 'The Utility of Bilateral Investment Treaties in the Formulation of Customary International Law' (1993) 14 Northwestern Journal of International Law and Business 327-75.

Nagy, Csongor, 'Editorial: Missed and New Opportunities in World Trade' (2017) 58 Acta Juridica Hungarica 379-83.

42 Nagy (2017) 381.

43 European Commission (2018) link 16.

44 Víg and Hajdu (2018) 49.

45 Info Curia (2018) link 17. 
Sacerdoti, Giorgio, Bilateral Treaties and Multilateral Instruments on Investment Protection (Hague Academy of International Law 1997).

Stevanović, Vlastimir, 'Okrugli Sto: Strane Direktne Investicije - Defektno Efektne' (2001) 12 Ekonomist 25-28.

Studwell, Joe, How Asia Works (Profile Books 2013).

Vagts, Detlev, 'Minimum Standard' in Bernhardt, Rudolf(ed), 3 Encyclopaedia of Public International Law (North Holland Publishing 1997).

van Houtte, Hans, The Law of International Trade (Sweet and Maxwell 2002).

Víg, Zoltán, and Hajdu, Gábor, CETA and Regulatory Chill in Görög, Márta, Mezei, Péter (eds), A szellemi tulajdonvédelem aktuális kérdései (Current Issues of the Protection of Intellectual Property) (Pólay Elemér Alapítvány 2018) 44-54.

Vörös, Imre, A nemzetközi gazdasági kapcsolatok joga I. (Law of the International Economic Relations, Vol. I.) (Krim Bt. 2015).

\section{LINKS}

1. World Bank Open Data (2018) <https://data.worldbank.org/> accessed 12 October 2018

2. Ernst and Young (2018) <www.ey.com/gl/en/issues/business-environment/ey-attractivenesssurveys $>$ accessed 14 October 2018.

3. Investment Policy Hub of UNCTAD (2018) <http://investmentpolicyhub.unctad.org/IIA> accessed 12 October 2018.

4. United Nations Conference on Trade and Development (2005) <http://unctc.unctad.org/aspx/ index.asp $x>$ accessed 4 June 2005.

5. US Model Bilateral Treaty (2018) <https://ustr.gov/sites/default/files/BIT\%20text $\% 20$ for $\% 20$ ACIEP\%20Meeting.pdf $>$ accessed 22 November 2018.

6. Nippon Export and Investment Insurance (2018) <http://nexi.go.jp/e/> accessed 22 November 2018.

7. Overseas Private Investment Corporation (OPIC) (2018) <http://www.opic.gov> accessed 25 November 2018.

8. International Law Commission (2018) $<$ http://www.un.org/law/ilc/texts/treaties.htm $>$ accessed 25 November 2018.

9. ICSID (2018) <https://icsid.worldbank.org > accessed 26 November 2018.

10. OECD MAI (2018) <www.oecd.org/investment/internationalinvestmentagreements/multilateral agreementoninvestment.htm $>$ accessed 12 November 2018.

11. Energy Charter Treaty (2018) <https://energycharter.org/fileadmin/DocumentsMedia/Legal/ ECTC-en.pdf $>$ accessed 23 November 2018.

12. Multilateral Investment Guarantee Agency (MIGA) (2018) <http://www.miga.org $>$ accessed 17 November 2018.

13. US Department of State NAFTA cases $<$ http://www.state.gov/s/1/c3742.htm $>$ accessed 18 November 2018.

14. NAFTA Claims.com (2018) <www.naftalaw.org> accessed 18 November 2018.

15. European Parliament, Benefits of EU international trade agreements $<\mathrm{http}: / /$ www.europarl. europa.eu/RegData/etudes/BRIE/2017/603269/EPRS_BRI(2017)603269_EN.pdf> accessed 21 December 2018.

16. European Commission (2018) <http://ec.europa.eu/trade/policy/in-focus/ceta/> accessed 18 November 2018.

17. Info Curia $(2018)<\mathrm{http}: / /$ curia.europa.eu/juris/liste.jsf?num=C-284/16> accessed 20 November 2018. 